\title{
Crossing Borders and Building Walls in Right-Wing Uses of the Past
}

\author{
David Farrell-Banks
}

\begin{abstract}
Right-wing populist, nationalist and extremist groups frequently make discursive use of the past to support their political agenda. This contribution briefly examines the use of the 1683 Siege of Vienna in political discourses. It shows how certain parts of European heritage are mobilised globally to present a singular view of European identity as white and Christian. This identity is constructed in opposition to a Muslim and migrant 'other'. The contribution shows that this notion of European identity is used not as a call for European unity, but to serve nationalistic needs when utilised by far-right groups. Moreover, this piece calls for greater recognition of how heritages are mobilised across borders in the interests of advancing a politics of exclusion and division.
\end{abstract}

KEYWORDS

belonging, extremism, right-wing politics, European heritage, Siege of Vienna

The plural heritages of Europe (Whitehead et al. 2019) and understandings of what it means to be European, permeate beyond the physical boundaries of Europe as a place, wherever we choose to believe these boundaries lie. The heritages of Europe are, for some, a tool for the construction of notions of a European self and other (De Cesari and Kaya 2019). Facilitated by the affordances of digital media, understandings of particular European heritages are mobilised globally through newly emergent networks. Existing in the public domain, yet still largely out of view, the workings of these networks have recently burst into view. In doing so, they demand attention and force us to question how European heritage is being used, both within and beyond our perceived borders of Europe. This article assesses the use of a particular historical moment by rightwing groups globally. It demonstrates how European heritages can cross physical borders, while concurrently being used to foster division and construct physical borders as well as social barriers on a global scale. 


\section{The 1683 Siege of Vienna}

In June 1683, Ottoman Empire forces besieged the Habsburg city of Vienna. The siege lasted for over two months before being broken by allied Holy Roman Empire forces, ostensibly led by Jan III Sobieski, in September of 1683. The moment is viewed as the start of the long decline of the Ottoman Empire. For example, Stanford Shaw and Ezel Shaw's History of the Ottoman Empire and Modern Turkey, Volume 2 (1977) includes two maps in the preface. The first covers 'the Growth of the Ottoman Empire, 1280-1683', while the second covers the decline from 1683-1975. Similarly, at the Vienna City Museum at Karlsplatz, the gallery dedicated to the 1683 siege presents an account of the repelling of the Ottoman forces, following which the visitor emerges into a gallery dedicated to the emergence of modern Vienna.

This is, of course, an extreme simplification of a complex history of territorial changes in Europe (Herbjørnsrud 2018). In the century prior to the Siege, the Ottoman Empire had been involved in frequent conflict with, among others, Venice, the Polish-Lithuanian Commonwealth, and Iran (Shaw and Shaw 1977). In the 1660s, Habsburg incursions into Ottoman Transylvania precipitated a war around the Austrian border. Through these years, territory was won and lost as shifts in power played out across Europe and beyond. As Justin McCarthy (1997) notes, a narrative of clear rise and fall of the Ottoman Empire neglects the fact that the Ottoman Empire had existed for 400 years prior to 1683 and would continue for over 200 years. Indeed, in those years following Istanbul flourished as a city, prompting some to view the years following 1683 as a period of peace and stability for the Ottoman Empire (Greene 2015).

For certain political actors, such as Heinz-Christian Strache - former leader of the far-right Austrian Freedom Party, a far-right party which emerged from the remnants of the Austrian Nazi Party (Reiter 2019) - this historical moment clearly represents the point at which Europe begins to emerge in its modern form. Ruth Wodak and Bernhard Forchtner (2014) have discussed Strache's use of this past in detail, including his production of a comic book placing himself at the centre of the breaking of the 1683 siege. Through repelling the Ottoman Empire, Europe flourishes as a white, Christian continent. This view is frequently adopted in far-right political discourse. In the early 2000s, a far-right blog site entitled 'The Gates of Vienna' emerged. With a focus upon Islamophobic ${ }^{1}$ content, the blog has become a 
central player in a global far-right, anti-Muslim network (see Bridge Initiative Team 2020). The blog tasked itself with detailing a new phase in a long war. For contributors, Vienna - and by extension the Western world - was once again under threat from a Muslim 'other'. While this explicit connection of the events of 1683 to Islamophobic rhetoric in the present is often contained within these niche blogging sites, on occasion they have burst into public view in extreme forms.

\section{3 and Right-Wing Extremism}

In July 2011, a right-wing extremist ${ }^{2}$ launched violent attacks on Oslo and a nearby gathering of the Workers Youth League, killing 77 people. The terrorist, prior to embarking on the attack, released a manifesto online entitled '2083: A European Declaration of Independence'. The year 2083 here acts as a reference to the 400th anniversary of the breaking of the Siege of Vienna. For the Oslo attacker, 2083 would mark the point at which Europe would finally achieve independence as a white and Christian continent, free from any Muslim presence. He viewed himself as acting to protect Europe against 'the great replacement' - the far-right conspiracy which suggests that a secretive power in Europe is allowing the slow conversion of the continent to being majority Muslim. The manifesto was inspired by the writings of a particular blogger on Gates of Vienna (Vikås et al. 2011).

In March 2019, another right-wing extremist opened fire on worshippers outside mosques in Christchurch, New Zealand. He killed 51 people. The attacker in this instance wrote a series of slogans, names and dates onto his weaponry. References were made to other right-wing extremists and, echoing the Oslo attacks, also to historical defeats of the Ottoman Empire. 'Vienna 1683' featured on one of these weapons. As was the case in Oslo, a manifesto was released prior to the attack taking place. This manifesto spoke of the 'Great Replacement', a racist conspiracy theory that claims that a Christian European culture is slowly being replaced by Muslim incomers. Again, this is a conspiracy theory spread through blogs such as Gates of Vienna (see Lazaridis et al. 2016).

These extreme actions are on the violent edge of an international right-wing use of European heritage. These examples illuminate how the use of heritage across borders is not in itself inherently positive. Heritage and the sharing of knowledge of our pasts are often considered in terms of their positive potentials. However, uses of the 
memory of 1683 draw attention to how interpretations of the past foster division. Through the remainder of this article, I will consider the role of digital media in facilitating this cross-border use of the past. While I focus on the 1683 siege, I shall briefly introduce other cases related to right-wing politics, although not always extremism, in which European pasts have been used transnationally to foster division. Finally, I will question our understanding of European borders and provoke a consideration of the role of transnational nationalisms.

\section{Shared Pasts, Nations and Transnational Belonging}

Montserrat Guibernau (2013) compellingly argues for the importance of belonging in political movements (see also Eckersley 2017). Building on Anderson's (1983) notion of the 'imagined community' of the nation-state, Guibernau believes that it is through the development of a sense of collective belonging that nation-states continue to hold a dominant role. Moreover, she notes that a sense of belonging is built on five dimensions (psychological, historical, cultural, territorial and political [2013: 125-128]. Here I focus upon the role of the historical. For Guibernau, the sense of a shared history, or what Eric Hobsbawm and Terence Ranger [1983] would view as 'invented traditions', allows a group to consider themselves to have a shared ancestry and, therefore, shared values. Elsewhere this role of the past in the development of shared identity might be viewed as facilitated by the collective memory of a nation-state [Nora 1996-1998; Olick 2007]. Here we can consider shared identity as the process by which individual identities, which make each individual unique, give way to group values and attributes [Guibernau 2013]. Within critical discourse studies, attention is given to the semantic role of such constructed shared pasts within political propaganda [i.e. Wodak 2015]).

In the rhetoric of extreme right-wing groups, references to the 1683 Siege of Vienna serve to both construct the sense of a shared history and articulate a need for political action. This is seen most clearly if we take the example of the right-wing activist group Gedenken 1683 (G1683), a branch of the Identitäre Bewegung Österreich (IBÖ, Identitarian Movement Austria, see Nissen 2020). Each September, this group holds a 'commemorative march' to the breaking of the 1683 Siege. The procession usually includes the carrying of banners and flaming torches, creating a visual atmosphere that will be familiar to those who followed the 'Unite the Right' protests in Charlottesville 
in the United States. Behind the physical procession, however, is a network of political discourse that constructs a vision of Austrian, European and Western identity upon the breaking of the 1683 Siege.

The G1683 website presents this march as the recognition of Austrian heritage and, importantly, an assertion of a patriotic sense of identity. They first state that 'history is for us not merely something for the past, but rather is an elemental component of our identity and therefore essential to our present and future'. This sentence concurs, in isolation, with broad understandings of the role of heritage and collective memory in society. However, the statement goes on to argue that G1683 are committed to a 'positive and identity-creating approach' to this memory which is 'explicitly patriotic'. The form of this patriotic vision is revealed in overlapping relationships between G1683 and the IBÖ. These groups are formed of the same people, with the leadership of the IBÖ using the G1683 plaform to attract new members under the guise of commemoration. It is a patriotism that is built on notions of 'traditional values' and the notion of 'remigration' - the return of non-native Austrians to their countries of origin. The purpose of the G1683 is to mobilise these ideals through the cover of commemoration of heritage and history. It is a use of the past that, via social media, becomes part of transnational right-wing discourse.

Initially, the discourse of the IBÖ and G1683 is focused on an Austrian national and Viennese audience. It primarily concerns protecting national borders from a constructed threat from the Muslim and migrant 'other', with a shared belonging built on nation-state identity. However, through the sharing of such discourse online this content also seeks to traverse borders. This discourse takes the physical, rooted activity of the procession and projects its relevance to a European colonial diaspora, to all those who might consider themselves to uphold the same version of European identity.

In 2019, content shared online at the time of the commemorative marches included a series of short biographies of key figures in the breaking of the Siege. These accounts further solidified the notion that this was an act of protection, not just for Austria but for Europe. These figures are presented as heroic for the role that they played in protecting a white and Christian Europe from an invading other. The memory of Jan III Sobieski, for example, is valorised as a reminder that 'it is possible to fend off the greatest dangers as long as the peoples of Europe stand together'. This calls upon the target audience, the members of the constructed in-group, to emulate these heroic 
figures by endorsing the political messages of groups such as IBÖ and G1683, and to protect Europe from dangers in the present. This message can be applied to the construction of borders transnationally. Here, a notion of European identity becomes an ideal which can be applied to an individual nation-state but can equally be adopted and shared transnationally. The breaking down of borders, facilitated by digital communication, allows for the reinforcement of the perceived need for borders.

Through the construction and dispersal of right-wing discourse then we can see the diffusion of notions of European identity to include colonised nations. In the years prior to undertaking the horrific attack in Christchurch, the terrorist attacker had visited Europe and spent time with the founders of the IBÖ (Hope Not Hate 2019). So impressed was he by their organisation that he donated funds to them following his visit. The visit itself speaks to a sense of pilgrimage, to the origins of an identity that the attacker viewed as integral to notions of what it meant to be a New Zealander. To be a colonial state meant adopting the same constructed identity as that in Europe.

\section{Uses of European Pasts}

This use of European pasts is, I argue, not confined to fringe, extremist examples. While groups such as the IBÖ have a small active membership, there is a broader relevance to the way references to 1683 have spread online. Elsewhere I have detailed the use of references to Magna Carta in transatlantic right-wing discourse (Farrell-Banks 2020). The manner in which Magna Carta is, on occasion, used politically echoes the uses of 1683 by supporters of the English right-wing activist Stephen Yaxley-Lennon (more frequently known as Tommy Robinson). Through Twitter, these messages of support came not solely from the UK, but also from global right-wing commentators such as Ezra Levant, the founder of the Canadian right-wing blog Rebel News. As with references to 1683, Magna Carta was shown to communicate a sense of Western exceptionalism. This exceptionalism is shown to have a deep history and, by extension, members of a constructed in-group are called upon to defend this exceptionalism against a perceived threat.

Again, the affordances of digital media facilitate the spread of global reference points within this form of right-wing activism. In the past, attention had been given to the potential for social media to 
act as a liberation technology (Diamond 2010). This notion has been dismissed more recently, as these technologies are more frequently viewed as upholding pre-existing power structures or as a threat to democracy (Tucker et al. 2018). However, returning to this notion of a 'liberation technology' might be productive if we consider who is being liberated and from what constraints. The role of social media in the transnational mobilisation of recent forms of right-wing activism speaks to a liberation from geographical and temporal constraints.

The groups discussed in this short piece each have a primary focus upon the construction and maintenance of physical borders. For G1683 there is a desire to close Austrian borders to non-white and Muslim migration. In publicising the 'great replacement' conspiracy theory, they call not only for the stronger policing of the borders of Austria, but also the significant closure of borders on a global scale. For political actors influenced by groups such as G1683, the focus on border protection is transferred to their own national circumstance. The Christchurch and Oslo terrorists saw a need to protect New Zealand and Norway, respectively, from immigration. For the Christchurch terrorist, this perceived threat was represented by Muslim populations worshipping at their local mosque. In the Oslo case, the terrorist targeted the youth wing of the then ruling Norwegian Labour Party who he viewed as responsible for the perceived dangers of multiculturalism. The spread of ideas which helped foment this form of violent extremism takes place across a global network of actors. Actors within each nation-state present their own national agenda. They are, however, united in a conception of a European, or Euro-centric, exceptionalism that traverses these borders.

\section{Conclusion}

The use of chosen historical moments in political debate illuminates the paradoxical relationship between the anti-migration, border-enforcing narratives of these right-wing political actors and their global, crossborder collaboration. This is a knowing paradox, one built upon a sense of white, western superiority and is reinforced, for a particular audience, through careful reference to historical moments that are claimed to show the deep historical legitimacy of this superiority. Such exceptionalism, while rooted in ideas of European identity, is communicated transnationally to nations whose colonial histories allow them inclusivity in a European 'in-group' identity. The right-wing groups discussed 
here seek to reiterate the need for closed borders, for an opposition to migration. These borders, however, are only applied to those who do not meet the requirements of a white, Christian, European 'in-group'. For those who are part of this in-group, transnational movement and interaction is legitimised by their superiority.

By tracking uses of certain pasts we can see deep historical ideas that find use in the present. They are given relevance to target groups as they are said to reveal something about that group's identity, in this instance European identity, in the present. When used in forms of farright activism, this by definition draws attention to how terrorists and right-wing activists mobilise these pasts to legitimise violence. The global violence signalled here remind us that the same racist sense of exceptionalism which characterises parts of European history, from colonial projects to mid-twentieth century fascism, continues to exist in the present. Such processes are often fuelled by the histories of those same racist projects. Divisive visions of European identity cross international borders, while seeking to reinforce those borders. Recognizing this dynamic is central to our understanding in order to better combat these forces of division.

\section{Acknowledgements}

The research detailed in this contribution was made possible by doctoral funding from Newcastle University Research Excellence Academy.

David Farrell-Banks, Cultures of Memory

Research Group, Newcastle University.

E-mail: David.Farrell-Banks@newcastle.ac.uk

\section{Notes}

1. 'Islamophobic' as used here takes the Runnymede Trust's 2017 definition of Islamophobia as anti-Muslim racism. A reference to 'Islamophobic' content should be understood as clearly describing this content as racist. Full definition: Elahi et al. 2017.

2. This contribution deliberately opts against granting named recognition to the perpetrators of terrorist attacks. 


\section{References}

Anderson, B. (1983), Imagined Communities: Reflections on the Origin and Spread of Nationalism (London: Verso).

Bridge Initiative Team (2020), 'Factsheet: Gates of Vienna', https://bridge.georgetown.edu/research/factsheet-gates-of-vienna/ (accessed 15 January 2021).

De Cesari, C. and A. Kaya (2019), European Memory in Populism: Representations of Self and Other (London: Routledge).

Diamond, L. (2010), 'Liberation Technology', Journal of Democracy 21, no. 3, 69-83, https://doi.org/ 10.1353/jod.0.0190

Eckersley, S. (2017), 'Changing Places, Changing People: Critical Heritages of Migration and Belonging', Anthropological Journal of European Cultures 26, no. 2: 1-5.

Elahi, F. and O. Khan (eds) (2017), 'Islamophobia: Still a Challenge For Us All. A 20th-Anniversary Report', www.runnymedetrust.org/uploads/Islamophobia\%20 Report\%202018\%20FINAL.pdf (accessed 15 January 2021).

Farrell-Banks, D. (2020), '1215 in 280 Characters: Talking about Magna Carta on Twitter', in A. Galani, R. Mason and G. Arrigoni (eds), European Heritage, Dialogue and Digital Practices (London: Routledge), 86-103.

Greene, M. (2015) The Edinburgh History of the Greeks, 1453 to 1768: The Ottoman Empire (Edinburgh: Edinburgh University Press).

Guibernau, M. (2013), Belonging: Solidarity and Division in Modern Societies (Cambridge: Polity).

Herbjørnsrud, D. (2018), 'The Real Battle of Vienna', Aeon, 24 July, https://aeon.co/ essays/the-battle-of-vienna-was-not-a-fight-between-cross-and-crescent (accessed 15 January 2021).

Hobsbawm, E. and T. Ranger (1983), The Invention of Tradition (Cambridge: Cambridge University Press).

Hope Not Hate (2019), 'More Links Between Generation Identity and Christchurch Mosque Killer Emerge', www.hopenothate.org.uk/2019/05/15/more-linksbetween-generation-identity-and-christchurch-mosque-killer-emerge/ (accessed 1 February 2021).

Lazaridis, G., M. Polymeropoulou and V. Tsagkroni (2016), 'Networks and Alliances against the Islamisation of Europe: The Case of the Counter-Jihad Movement', in G. Lazaridis and G. Campani (eds), Understanding the Populist Shift: Othering a Europe in crisis (Oxon: Routledge), 70-103.

McCarthy, J. (1997), The Ottoman Turks: An Introductory History to 1923 (New York: Addison Wesley Longman).

Nissen, A. (2020), 'The Trans-European Mobilization of "Generation Identity", in O.C. Norocel, O.C., A. Hellström and M.B. Jørgensen (eds), Nostalgia and Hope: Intersections between Politics of Culture, Welfare, and Migration in Europe (Cham: Springer Open), 85-100.

Nora, P. (1996-1998), Realms of Memory, abridged translation (New York: Columbia University Press).

Olick, J. K. (2007), The Politics of Regret: On Collective Memory and Historical Responsibility (London: Routledge).

Reiter, M. (2019), Die Ehemaligen: der Nationalsozialismus und die Anfänge der FPÖ (Düsseldorf: Wallstein Verlag). 
Shaw, S.J. and E.K. Shaw (1977), History of the Ottoman Empire and modern Turkey. Volume 2, Reform, Revolution, and Republic: The Rise of Modern Turkey, 1808-1975 (Cambridge: Cambridge University Press).

Tucker, J. A., Guess, A., Barbera, P., Vaccari, C., Sigel, A., Sanovich, S., Stukal, D. and B. Nyhan (2018), Social Media, Political Polarization, and Political Disinformation: A Review of the Scientific Literature (Menlo Park, CA: Hewlett Foundation).

Vikås, M., Widerøe, R.J., Ravndal, D., Torgensen, H. H., Brenna, J. G., Andersen, G. \& M. S. Hopperstad (2011) 'Breivik's Political Idol "Fjordman” Emerges from Anonymity', VG, 27 September, www.vg.no/nyheter/innenriks/i/2Q5d4/breivikspolitical-idol-fjordman-emerges-from-anonymity (15 January 2021).

Whitehead, C., Daugbjerg, M., Eckersley, S. and G. Bozoğlu (eds) (2019), Dimensions of Heritage and Memory: Multiple Europes and the Politics of Crisis (London: Routledge).

Wodak, R. (2015), The Politics of Fear: What Right-Wing Populist Discourses Mean (London: Sage).

Wodak, R. and B. Forchtner (2014), 'Embattled Vienna 1683/2010: Right-wing Populism, Collective Memory and the Fictionalisation of Politics.', Visual Communication 13, no. 2: 231-255. 